\title{
Global Language: New Opportunities or Inferiority Complex*
}

\author{
Svetlana Soboleva \\ Far Eastern Federal University, Vladivostok, Russia
}

\begin{abstract}
Globalization has long ceased to be interpreted solely in terms of economics. Indeed, it involves all spheres of human activity, cross-cultural communication being crucial. Three-four decades ago the idea of speaking a single international language seemed as promising and beneficial as the idea of using a single international currency. In light of the recent failure of multiculturalism in Europe the debate about the future of the lingua franca and its efficiency became heated. The status of the English language in the East is different from that in the West. While in Europe and Africa, English is challenged by French and German, in South and North America, by Spanish, in South East and North East Asia the English language enjoys a red carpet welcome. In this part of the world, people prefer English as a second language over the languages of their neighboring countries. There are both pros and cons to this approach.
\end{abstract}

Keywords: lingua franca, national identity, Inner circle, Outer circle

\section{Introduction}

The steady growth of international contacts in the humanitarian sphere of life is definitely a positive phenomenon though the outcome of numerous conferences and symposiums might have been more tangible. One cannot but feel a certain inconsistency between the expressed intentions of the conferees and rather feeble actual results of their pursuit. It is not as if they did not arrive at mutually acceptable solutions or did not mean to implement them. The international community has no reason to complain. But somehow the human life globally has not become more safe or peaceful. Indeed, one-fourth of all nations on this planet is currently at war and has been for a decade. The humanitarian crisis that people are suffering from has been predicated by a wide range of reasons: from religious clashes to gender conflicts. Humanity will not come to agreement on any single issue. The only point that seems to be more or less settled is the language of international communication. The lack of global instrument of communication has generally been viewed as the major reason for military conflicts since the days of Babel. In the late 20th century, the English language was universally accepted as a lingua franca, but wars did not cease. Presumably cross-cultural misunderstanding, though an aggravating impediment, can hardly play a significant role where competition for resources and leadership are on the agenda. Still, the English language is in the centre of the agitated debate. Linguists, educationalists, administrators, university professors, and ministerial officials concentrate on a variety of questions, mainly "Teaching Methods", "Assessment", and "British (American) Culture in the Language Classroom". The deep impact of the English language on the individual and national psychology of the recipients is seldom if ever

\footnotetext{
* This work was supported by the Far Eastern Federal University project No. 14-08-05-14_и.

Svetlana Soboleva, associate professor, Ph.D. candidate, School of Regional and International Studies, Far Eastern Federal University.
} 
touched upon.

\section{New Language and New Values}

Euphoria over the advantages of speaking a lingua franca is gradually giving way to disappointment. The pendulum has swung the other way. Honestly speaking, English is not the first lingua franca which the humankind opted for. A dozen languages, both natural and creole, are known to have been vehicles of international communication in different periods of time. Suffice it be to mention just a few of them-Latin, French, Classical Chinese, Esperanto, Lingua Franca Nova. Among them, Lingua Franca Nova stands out as the rival of the global English. It was created in the mid 1960s as a blend of Romance languages and is now used online by some enthusiasts. From the very beginning, Lingua Franca Nova has definitely been opposed to the English language in terms of culture and dominance. One of its designers, Alan Corre emphasized the fact that:

English has come to represent a specific cultural tradition... including industrial society, commercialism, free-market orientation, individualism, media dominance, and unfortunate colonial histories. While not all these things are necessarily bad (and are in fact emulated), they are not appealing to everyone, especially countries who feel their cultural traditions slipping away under the bombardment of the English language movies, radio, television, music, products, and now the Internet. (as cited in Boeree, 2014)

Generally Europeans are reluctant to speak English if they can afford not to speak it. They fear very much lest their national identity should be replaced by the newcomer. Thus, the French and Italian speakers in Switzerland appear to be uneasy about the progressive abandonment of their languages by the German-speaking community in favor of English:

German-speaking cantonal governments have been responding to what they say is pressure from the globalised economy by gradually giving English priority over the national languages at school; English—not French—is taught as a second language in 14 of the 17 cantons. (Burkhardt, 2014)

Such an attitude has been popular in Europe for quite a time and opinion polls which are now and then conducted by both media and academia support the observation of the French and Italian speakers in Switzerland.

\section{Methods}

The complex and ambivalent prospect of the lingua franca status needs a cautious approach. Time tested techniques of the survey method served as a basis for collecting a pool of opinions and views on the issue of the international English. The second step of the research which aimed at highlighting similarities and differences between opinion groups was the comparative study of the collected data. The third step involved analysis method and revealed the prevalent views concerning the status of the global English. At the final stage, the inductive method was used to summarize individual observations and to produce coherent generalization.

\section{Data Collection}

A wide range of views on the global spread of English was in the focus of this investigation. There were three major sources which provided reliable information about how English is perceived in different parts of the world, particularly in the Asia-Pacific region:

(1) BBC News page "Talking Point" of August 23, 2001 which was retrieved from its website 
http://news.bbc.co.uk/2/hi/talking_point/1490463.stm;

(2) The 19th International Conference of the International Association for Intercultural Communication Studies "Exploring Diversity to Reach Understanding Across Cultures", Vladivostok, Russia, October 3-5, 2013;

(3) The 11th Asia TEFL International Conference "English across Asian Contexts: Opportunities and Challenges", Ateneo de Manila University, Philippines, October 26-28, 2013.

The opinions which were expressed by the conferees in published research papers and abstracts as well as those which were pronounced at workshops, sessions, and seminars contributed to the data bank of this study.

\section{Discussion}

On August 23, 2001, BBC News posted on its website a short information message:

European Commissioner Neil Kinnock has been accused of trying to increase the dominance of the English language in the European Union. The French and German foreign ministers have made a formal protest to the European Commission about his proposal to cut the bill for translating documents. They believe the plan — which would restrict some documents to the language in which they were written originally-would favour English. Marc Roche of "Le Monde" newspaper criticized Mr. Kinnock's plan: "It's a terrible idea... It's a perfidious British plot in order to transform the EU into a sort of English speaking area." BBC World Service Radio and BBC News On-line arranged the discussion of this issue live in their Talking Point phone-in programme. They asked their audience two questions: "Is English taking over as the dominant language in Europe and the rest of the world?" and "Should we all be speaking in one tongue or do we risk losing the cultural diversity of a multilingual world?" ("Talking Point," 2001)

Dozens of people from European and Asian countries got engaged in the discussion. Their approaches to the English language as a lingua franca ranged from rather benevolent to extremely exasperated. But still some tendencies could be traced. People depended on their job, education, origin, and welfare for the choice of the language to use in their workplace and at home. The following quotations show how similarly people see the role of the English language in their multilingual communities:

My case is special because I live in a French-speaking country but I hate French. This is why I spend most of my time learning English. I notice that everything around me is English - the American films, the Internet, etc. I think the French and the Germans are jealous, but they can't stop the influence of English in Europe because the USA dominate the world by their language—English. (Omar from Senegal, "Talking Point," 2001)

I am an Indian living in Germany for my studies. In these few months I have discovered that though they know English, people just do not wish to speak it. It's really difficult to survive in an EU country unless you know its language. Even in public places like banks and shops, I find people who just don't want to speak English. Even in the university, where there are lots of foreign students from all parts of the world, the talks and seminars are generally in German, which is really very stupid. So I believe that if they all spoke English, life would be easier here and more people would come. (Garima Khare from India, “Talking Point," 2001)

English as an international language is used all over the world. Every person must know English to learn about world. So English is an important language. (Yubaraj Pandey from Nepal, "Talking Point,” 2001)

I'm from Eastern Europe and I'm working now in France as IT programmer. Well, in this country those that speak English are rare birds - even my French colleagues. In my country, as poor as she is, a lot of people are talking very good English. Why here on the continent the people are so stupid and do not understand that without a common language you can't talk about European Union? English is the best solution. (Mihai from Romania, “Talking Point,”2001)

Doesn't everybody use automobiles, doesn't everybody use electricity, doesn't everybody use computers? Who cares about where all these inventions come from? Everybody should use English. Who cares if it came from England. (Narayan 
from India, “Talking Point," 2001)

The keynote of these quotations is very loud: “...everything around me is English...”, “...they know English...”, “...if all spoke English life would be easier", "English is used all over the world”, "Every person must know English”, “...a lot of people are talking very good English", "Everybody should use English". Speaking workable English is absolutely essential for those who want to advance on the ladder of success. And who does not? The above quotations prove that the first reason to take English as a foreign language is to get involved in the global labor and communication. Non-native English language speakers do not see English as a way of self-expression. For them English is reduced to "an instrument", "a means", "a tool", or "a vehicle". Never will they look on the English language as an indispensible part of their selves. This attitude is wholly a product of globalization. In his article "Opinions on the Social and Cultural Impact of English as an International Language", David Jeffrey McLachlan (2014) observed that: "the media and the educational systems are the most important direct agents in language murder today; indirectly the culprits are the global economic and political systems".

It looks as if lingua franca were considered in terms of a single international currency, like the dollar or the euro. The advantages of using a single currency are apparent, consequently, the advantages of speaking a single language also seem undeniable. Alan Chambers from Poland remarked:

Just ask yourself one thing about Europe. They all want a single currency and they all are happy, it would appear, to live in a quasi-federal society. So what's wrong in having one language? You pays your money and takes your choice. (“Talking Point," 2001)

The opinions from different regions of the world which BBC posted on their website in 2001 suggest that learners' preference of English correlated with their places of origin: While Asian audience often expressed opposing viewpoints and failed to form a homogeneous group, people from Eastern and Central Europe appeared quite sympathetic toward "the English language conquest", and West Europeans felt irritated and reluctant to speak English:

English as a world language is very widespread and it does not need a new push. The commission should concentrate rather on promoting the linguistic diversity of the EU instead of promoting English! And why English and not French? (Juan de Sades from Spain, "Talking Point," 2001)

These days the global tendencies of the English language are more pronounced. Recent polls reveal that it is the high level of income and education rather than the birthplace that influence the choice of the foreign language. In 2012 Ipsos Global Public Affairs conducted the poll for Reuters. The conclusion which they arrived at, though predictable, highlighted a new aspect of the English-speaking practices. "The most revealing aspect of this survey is how English has emerged as the default language for business around the world," said Darrell Bricker, CEO of Ipsos Global Public Affairs (Michaud, 2012).

Workers whose jobs require them to interact with people in foreign countries say that English is the dominant language of business. Bricker said the findings proved that:

all those in the English-speaking world who suggested that our children should learn Mandarin or Japanese to have successful careers were beaten to the punch by the Chinese, in particular, learning English first. The survey showed that people with higher levels of income or education were among the most likely to say English was most commonly used for foreign business relationships. Gender and age had no bearing on the dominant language for conducting business. (Michaud, 2012) 
Erasing distinctions between nations, genders, age groups, religious and political affiliations, testifies to the global status of the English language in the most indisputable way. English turned into a sterilized instrument which is used to cut a perfect employee from an amorphous individual. This instrument is indifferent to personal accomplishments unless they serve the purposes of business. Thus, the use of the local vernacular languages in the global market place impedes commercial growth and therefore ought to be restricted, whereas the use of the international vehicular language which promotes global business ought to be in every way encouraged. Ambitious learners of English do not even realize that the language which they see as the booster of their career may provide them with a direct access to the richest culture that was ever created. Ambitious learners are only aware that English may provide them with a direct access to social prestige and allow them to enter into the world of richness and supremacy, in other words, obtain the assets which are associated with American leadership, "because the USA dominate the world by their language-English" (Omar from Senegal, "Talking Point,” 2001).

Bilingual speakers of English from Asia-Pacific countries admit that for them to speak English is to think like Americans. English is the language of the winner and everybody wants to be on his side. This is the psychological aspect of the global spread of English. Are international learners of English ready to give up part of their national identity which they acquired through their mother tongues in order to get access to Americanized values? Some learners will only be too glad to say "Yes." Or rather "Wow, it's cool!"

It is worth noting that the factors resulting in the unprecedented spread of English are interpreted in a similar way by both its opponents and supporters, but the conclusions they arrive at are opposite. The former believe that English ought to be rejected because it jeopardizes their national identity. The latter feel that it ought to be accepted because it may reinforce their identity, so they do not mind substituting the English language for their mother tongue.

The following viewpoint serves a good illustration of why the English language is gaining ground in Ukraine, the territory which is on its way to join the West:

English is the language of Hollywood, show biz, and rap, of business communication and the Fifth Avenue, it is the language of the Internet; we may say it is the language of money. The pointless dispute of the local politicians on the language problem ought to be put an end to for the sake of the future generation. In terms of evolution this dispute is useless. (Berestenko, 2014)

"English is the language of money" truly and honestly explains why English will continue to conquer the hearts of people all over the world. The Ukrainian champions of English go as far as to suggest the transition of the Ukrainian language from Cyrillic to Latin so as to be "linguistically closer" to their goal.

\section{Mother Tongue or Lingua Franca}

The advantages of the global English language are well known. Are the advantages of mother tongues also known to the people who speak these tongues but will readily give them up in favor of the international English? The question remains open. The role of the native language in shaping personality is usually underestimated. But the fact remains that the world which people see around them has actually been created by their mother tongue because the elements of this world are described in terms of this tongue. The people's national identity is reflected in their language.

Linguistic anthropologists maintain that the language which individuals acquire at birth is gradually turning into the iconic immune system which serves to protect their identities against the alien impact, be it 
psychological, cultural, or emotional.

The national language also protects a nation against expansionism of the neighboring nations. The stories and tales that people hear in their childhood are told to them in their community in their language. The nation and the national identity become associated with the national language which serves to encourage confidence, pride, and faith in people. These are the feelings that constitute full-fledged personalities and citizens. Native speech unites "my people" and distinguishes them from "the other people" (Markov, 2011); it really works like "friend"-"foe" identification system.

Two centuries ago, people had no problems with self-identification because their medium was homogeneous. There was no threat of globalization. The ancestors spoke the same language and articulated the same sounds as the personages of their songs and tales. In this way the nation's historic, cultural, and linguistic identity was preserved. The urgent need for cross-cultural communication that humankind has been experiencing for the last 25-30 years shook the foundations of this harmony. Globalization has eroded the ethnic and historic origins of nations and instead of producing well-rounded men of the world with global coherent vision it has produced isolated neurotic nationalist individuals with a deeply rooted inferiority complex.

The inferiority complex is something very humiliating that awaits the naive learners of English in the countries of the so-called "norm developing Outer circle". India, Singapore, Jamaica, the Philippines, and over 50 other territories are included in this circle. The privileged "norm providing" Inner circle is constituted by the United Kingdom, the United States, Canada, Australia, and New Zealand. Everybody understands what it means "to provide the norm" and everybody finds it only natural for the nations who develop their identities through English to set the rules of the language. The politically correct term "to develop the norm" is misleading the learners of English in the Outer circle who believe that they are also allowed to make their contributions to the English language and in this way "develop" it. The opinion expressed in the following quotation is quite common in the Outer circle:

Those for whom English is a mother tongue, have a powerful advantage in that they have to work less to communicate in the business, scientific and educational worlds. However the flip side is that these peoples don't have a "private" language anymore and unless they comply with dominant standards of usage (e.g. the different sense in which "table a meeting" is used in the US and UK) they stand to be misunderstood. (Michael Chee from Singapore, "Talking Point," 2001)

This is an uneasy prediction. If it came true English might lose its lingua franca status.

\section{Conclusion}

Many non-native speakers honestly believe that they will be allowed "to develop the norm" of the English language. Innovative suggestions on how "to expand the potentialities of the English language" by legalizing neologisms like "need of* help", "to arrive to* town", "to look on* the picture", etc. can often be heard at TESOL and TEFL conferences. Foreign students of English are encouraged to feel uninhibited as if English were their mother tongue. This is nothing but wishful thinking. No matter what the advocates of Kachru's classification of World Englishes may maintain the Inner circle speakers of English refuse to recognize the Outer circle as "perfect" speakers and never fail to tell them that "they do not belong". Politically correct concept of "transference" does not work when Outer circle comes in contact with Inner circle. "People in the street" in Great Britain or the United States never attend international conferences on cross-cultural 
communication and are quite unaware of political correctness.

Feeling confused and embarrassed Singaporeans, Filipinos, and other Outer Circle speakers persist in proclaiming their norm developing status at international conferences and symposiums. Although British and American educationalists benignly agree to let them enjoy this status, there is no denying the fact that it is "people in the street" rather than university professors who have the final say. Teachers of English from Singapore bravely admit that they experience this kind of awkwardness and are determined to fight it (Low, 2013). With the economic rise of South-East Asia and the growing global interest in the languages, culture, and history of this part of the world they will increasingly find their mission rewarding. Reliance on the mother tongue and national background is the best prophylactic against inferiority complex.

\section{References}

Berestenko, K. (2014, November 22). Luchshyi genotsyd natsii (The best genocide for a nation). Retrieved from http://vz.ru/club/ 2014/11/21/715607html

Boeree, C. G. (2014). Frequently asked questions. Retrieved from http://elefen.org/faq.html

Burkhardt, M. (2014). SWI: Balancing national and global language needs. Retrieved from http://www.swissinfo.ch/eng/ balancing-national-and-global-language-needs/40803504

Crystal, D. (2003). English as a global language. New York: Cambridge University Press.

Detering, D. (2010). ELF-based pronunciation teaching in China. Chinese Journal of Applied Linguistics (Bimonthly), 33(6). Retrieved from www.ubd.edu.bn/academic/faculty/FASS/staff/docs/DD

Jenkins, J. (2007). English as a lingua franca: Attitudes and identity. Oxford, UK: Oxford University Press.

Johnson, A. (2009). The rise of English: The language of globalization and the European Union. Retrieved from http://digitalcommons.macalester.edu/do

Li, S. (2013). Diversity, intercultural citizenship, and critical language-cultural awareness in foreign language education. In Exploring Diversity to Reach Understanding across Cultures. The 19th International Conference of the International Association for Intercultural Communication Studies (p. 15). Vladivostok: Far Eastern Federal University.

Low, E. (2013). Non-native English speakers and pronunciation teaching: Myths, realities and practicalities. In Proc., 11th Asia TEFL International Conference. Manila: Ateneo de Manila University.

Markov, B. V. (2011). Lyudi i znaki (People and signs). St. Petersburg: "Nauka" Publishers.

McLachlan, B. J. (2014). Opinions on the social and cultural impact of English as an international language. Retrieved from http://www.nuis.ac.jp/ hadley/publication/jeffrey/Jeffrey-EIL.htm

Michaud, R. (2012). English the preferred language for world business: Poll. Retrieved from http://www.reuters.com/article/2012/ 05/16/us-language-idUSBRE84F0OK20120516

Schneider, E. W. (2007). Postcolonial English: Varieties around the world. New York: Cambridge University Press.

Talking point: Is the English language conquering Europe?. (2001). BBC News. Retrieved from http://news.bbc.co.uk/2/hi/talking point/1490463.stm

Ter-Minasova, S. G. (2000). Yasyki i mezhkulturnaya kommunikatsuya (Languages and cross-cultural communication). Moscow: Slovo. 